\title{
Skojarzone leczenie nadciśnienia tętniczego i hipercholesterolemii: inhibitor konwertazy angiotensyny, antagonista wapnia i statyna - wygoda stosowania, bezpieczeństwo, skuteczność
}

\author{
Hypertension and hypercholesterolemia treatment: \\ combination of ACEI, calcium antagonist and statin
}

\author{
Katarzyna Starzyk ${ }^{1}$, Beata Wożakowska-Kapłon ${ }^{1,2}$ \\ ${ }^{1}$ I Klinika Kardiologii i Elektroterapii Świętokrzyskiego Centrum Kardiologii w Kielcach \\ ${ }^{2}$ Wydział Lekarski i Nauk o Zdrowiu Uniwersytetu Jana Kochanowskiego w Kielcach
}

\section{Streszczenie}

Nadciśnienie tętnicze i hipercholesterolemia stanowią najczęstsze czynniki ryzyka miażdżycy w polskiej populacji. Hipercholesterolemia występuje aż u około $2 / 3$ dorosłych Polaków, natomiast nadciśnienie tętnicze jest najczęstszym schorzeniem kardiologicznym, dotykającym 1/3 populacji dorosłych Polaków, pojawiającym się szczególnie często u osób po 50. roku życia. Zarówno nadciśnienie tętnicze, jak i hipercholesterolemia są słabo kontrolowane u polskich pacjentów. Aby poprawić skuteczność terapii i obniżyć ryzyko sercowo-naczyniowe (CV) pacjenta, a jednocześnie ograniczyć efekt słabej współpracy lekarza i pacjenta, należy rozważyć leki złożone (połączenie leków hipotensyjnych i statyny) w terapii czynników ryzyka miażdżycy, w których samowolna modyfikacja dawek składowych preparatu nie jest możliwa. Celem leczenia hipolipemizującego, z zastosowaniem statyn, jest osiąganie docelowego dla danej populacji stężenia cholesterolu frakcji LDL. Większość pacjentów leczonych z powodu nadciśnienia tętniczego wymaga zastosowania 2 lub więcej leków, aby osiągnąć prawidłową kontrolę ciśnienia tętniczego krwi, czyli poniżej 140/90 mm Hg. Zastosowanie preparatów złożonych, dzięki redukcji częstości występowania działań niepożądanych, poprawie tolerancji przez chorego i polepszeniu komfortu życia, przyczynia się do przestrzegania zaleceń lekarskich. Rodzaj leczenia hipotensyjnego ma znaczenie, ponieważ na przykład w badaniu ASCOT, dzięki połączeniu atorwastatyny z perindoprilem i amlodipiną, zredukowano ryzyko CV o 53\%, a po jej dodaniu do atenololu i diuretyku tiazydowego jedynie o 16\%. Zarówno nadciśnienie tętnicze, jak i hipercholesterolemia prowadzą do uszkodzenia funkcji śródbłonka oraz zwiększonej oporności na insulinę i w ten sposób sumują niekorzystny wpływ w procesie rozwoju miażdżycy tętnic. W terapii nadciśnienia tętniczego i hipercholesterolemii preparaty złożone pozytywnie wpływają na poprawę kontroli wartości ciśnienia tętniczego i przestrzeganie zaleceń lekarskich.

Słowa kluczowe: ACEl, amlodipina, statyna

Folia Cardiologica 2016; 11, 5: 427-432

Adres do korespondencji: dr n. med. Katarzyna Starzyk, I Klinika Kardiologii i Elektroterapii, Świętokrzyskie Centrum Kardiologii, ul. Grunwaldzka 45, 25-736 Kielce, e-mail: zikas@poczta.onet.pl 


\section{Wstęp}

Nadciśnienie tętnicze i hipercholesterolemia stanowią najczęściej występujące czynniki ryzyka miażdżycy w polskiej populacji. Hipercholesterolemię stwierdza się aż u około 2/3 dorosłych Polaków, natomiast nadciśnienie tętnicze jest najczęstszym schorzeniem kardiologicznym, dotykającym 1/3 populacji dorosłych Polaków, pojawiającym się zwłaszcza po 50. roku życia. Oba te czynniki, często występują łącznie, mogą prowadzić do rozwoju powikłań, takich jak udaru mózgu lub zawał serca, które pozostają główną przyczyną zgonów w naszym kraju. Wprawdzie dzięki zmianom w stylu życia Polaków od lat 90. do roku 2002 odnotowano zmniejszenie śmiertelności z przyczyn sercowo-naczyniowych (CV, cardiovascular), nadal utrzymuje się ona na wysokim poziomie [1, 2]. Częstość występowania zgonów z przyczyn CV w populacji osób powyżej 74. roku życia (WOBASZ SENIOR) wynosiła w latach 2003-2012 48\% u mężczyzn i 58\% u kobiet. Średnia długość życia Polaków, mimo stopniowego wydłużania się, wciąż jest o kilka lat niższa w porównaniu z krajami będącymi w Unii Europejskiej przed 2004 rokiem [2]. Za występowanie przedwczesnych zgonów w polskiej populacji w dużej mierze odpowiedzialne są tzw. czynniki ryzyka miażdżycy. W badaniu epidemiologicznym NATPOL 2011 wykazano główne czynniki ryzyka miażdżycy, takie jak nadciśnienie tętnicze (32\%), hipercholesterolemia $(60,7 \%)$, otyłość (22\%), cukrzyca typu 2 (5\%). Jedynie u 11\% dorosłych Polaków nie stwierdzono żadnych czynników ryzyka miażdżycy [3]. Nawet w młodszych generacjach (20-49 lat) zarówno hipercholesterolemię (42,7\%), jak i nadciśnienie tętnicze $(10,4 \%)$ stwierdzano w licznej grupie polskich kobiet, a cukrzyca występowała u 4,4\% badanych [4].

Zarówno nadciśnienie tętnicze, jak i hipercholesterolemia nie są dokładnie kontrolowane u polskich pacjentów. Wśród uczestników badania NATPOL 2011 26\% osób z nadciśnieniem tętniczym osiągało zgodne z wytycznymi obniżenie ciśnienia tętniczego krwi poniżej 140/90 mm Hg (w 2002 r. było to $12 \%$ chorych) i jedynie $8 \%$ osób z rozpoznaną hipercholesterolemią osiągało docelowe stężenia cholesterolu frakcji lipoprotein o niskiej gęstości (LDL, low-density lipoprotein) [3]. Wśród pacjentów z rozpoznaną już chorobą sercowo-naczyniową, czyli obciążonych bardzo wysokim ryzykiem sercowo-naczyniowym, w ciągu 6-18 miesięcy po ostrym zespole wieńcowym leczenie często okazuje się nieskuteczne. W latach 2010-1012 w populacji tych chorych aż $47 \%$ pacjentów było nieskutecznie leczonych z powodu nadciśnienia tętniczego, a stężenie cholesterolu frakcji LDL co najmniej $70 \mathrm{mg} / \mathrm{dl}$ ( $\geq 1,8 \mathrm{mmol} / \mathrm{l}$ ) występowało u $73 \%$ badanych. Ponadto stężenie $\mathrm{HbA}_{1 \mathrm{c}}$ powyżej $7 \%$ stwierdzono u 14\% chorych, $20 \%$ pacjentów nadal paliło papierosy, a u 80\% stwierdzano nadwagę lub otyłość [5]. W perspektywie kolejnych lat, ze względu na proces starzenia się społeczeństwa, należy się spodziewać wzrostu częstości występowania czynników ryzyka miażdżycy. Nawet u osób związanych ze służbą zdrowia, a więc posiadających wiedzę dotyczącą czynników ryzyka miażdżycy, w miarę upływu lat zaobserwowano wzrost wartości ciśnienia tętniczego krwi, stężenia cholesterolu i glukozy w surowicy krwi oraz wskaźnika masy ciała (BMI, body mass index) [6].

Aby poprawić skuteczność stosowanego leczenia, należy kontynuować i wzmóc działania, które zaowocowały zmniejszeniem śmiertelności CV w latach 2002-2011. W badaniu NATPOL PLUS zaobserwowano, że na zmniejszenie umieralności z przyczyn CV miały wpływ w 54\% zmiany stylu życia Polaków oraz - w nieco mniejszym stopniu - dynamiczny rozwój metod leczenia miażdżycy tętnic wieńcowych (37\%). Redukcję ryzyka CV w poprzednich latach osiągnięto jednak w największym stopniu dzięki zmniejszeniu średniego stężenia cholesterolu (redukcja ryzyka o 41\% u mężczyzn i 33\% u kobiet) oraz wartości ciśnienia tętniczego krwi (o 29\% u kobiet i 8\% u mężczyzn) [7].

Obecnie mamy do dyspozycji skuteczne metody leczenia hipercholesterolemii. Podstawą postępowania niefarmakologicznego jest zmiana stylu żywienia oparta na zasadach diety śródziemnomorskiej, a w farmakoterapii lekami pierwszego wyboru są statyny. Między rokiem 2002 a 2011 (w badaniach NATPOL) osiągnięto redukcję stężenia cholesterolu całkowitego o 0,21 mmol/l. Oszacowano, że aż 85\% tej redukcji jest zasługą stosowania statyn. Gdyby wybrano wyłącznie postępowanie niefarmakologiczne, redukcja wynosiłaby 0,03 dla całej dorosłej populacji badanej w 2011roku i 0,06 u pacjentów w wieku 60-79 lat [7]. Statyny należą do leków najczęściej przepisywanych w krajach rozwiniętych. W 2011 roku statyny stosowało $11 \%$ wszystkich respondentów projektu NATPOL 2011 i niemal 32\% osób w wieku 60-79 lat [3]. Podsumowaniem 22 randomizowanych badań, analizujących skuteczność i bezpieczeństwo stosowania statyn, jest metaanaliza CTT (Cholesterol Treatment Trialists'). Potwierdzono w niej korzyści ze stosowania terapii oraz osiągania celu zgodnego z aktualnymi wytycznymi. Wykazano, że leczenie statyną, przy redukcji stężenia cholesterolu frakcji LDL o każdy $1 \mathrm{mmol} / \mathrm{l}$ : zmniejsza śmiertelność całkowitą o 10\%, śmiertelność z przyczyn CV o 20\%, ryzyko wystąpienia poważnych zdarzeń sercowych o 23\%, a udarów mózgu o 17\%[8]. Redukcję ryzyka CV odnotowano już w pierwszym roku leczenia, niezależnie od wyjściowego stężenia cholesterolu LDL i płci pacjentów [8]. Niestety obserwuje się zaprzestanie terapii statynami aż u 15-75\% (średnio 50\%) chorych. W metaanalizie badań obserwacyjnych oszacowano, że odstawienie statyny wiąże się ze zwiększeniem częstości występowania incydentów sercowo-naczyniowych i zwiększeniem śmiertelności (porównywano osoby, które odstawiły lek, z pacjentami kontynuującymi zalecaną terapię) [9]. Przyczyną niestosowania leków tej grupy może być obawa przed występowaniem objawów mięśniowych. Rejestry pacjentów i obserwacje kliniczne wskazują, że 7-29\% 
Tabela 1. Docelowe wartości cholesterolu frakcji lipoprotein o niskiej gęstości (LDL, low-density lipoprotein) w zależności od poziomu ryzyka sercowo-naczyniowego u pacjenta z nadciśnieniem tętniczym

\begin{tabular}{|c|c|c|c|c|}
\hline \multirow{2}{*}{$\begin{array}{l}\text { Poziom ryzyka sercowo- } \\
\text {-naczyniowego }\end{array}$} & \multicolumn{4}{|c|}{ Stopień nadciśnienia tętniczego i wartości ciśnienia tętniczego [mm Hg] } \\
\hline & $\begin{array}{c}\text { Wysokie prawidłowe } \\
130-139 / 85-89\end{array}$ & $\begin{array}{c}\text { Stopień } 1 . \\
140-159 / 90-99\end{array}$ & $\begin{array}{c}\text { Stopień } 2 . \\
160-179 / 100-109\end{array}$ & $\begin{array}{l}\text { Stopień } 3 \\
\geq 180 / 110\end{array}$ \\
\hline \multicolumn{5}{|l|}{ Bez innych czynników ryzyka } \\
\hline 1-2 czynniki ryzyka & & $\mathrm{LDL}<115 \mathrm{mg} / \mathrm{dl}$ & $\mathrm{LDL}<115 \mathrm{mg} / \mathrm{dl}$ & $\mathrm{LDL}<100 \mathrm{mg} / \mathrm{dl}$ \\
\hline$\geq 3$ czynniki ryzyka & & $\mathrm{LDL}<115 \mathrm{mg} / \mathrm{dl}$ & $\mathrm{LDL}<100 \mathrm{mg} / \mathrm{dl}$ & $\mathrm{LDL}<100 \mathrm{mg} / \mathrm{dl}$ \\
\hline $\begin{array}{l}\text { Obecne uszkodzenia narzą- } \\
\text { dowe, cukrzyca, przewlekła } \\
\text { choroba nerek w stadium } 3 .\end{array}$ & $\mathrm{LDL}<100 \mathrm{mg} / \mathrm{dl}$ & $\mathrm{LDL}<100 \mathrm{mg} / \mathrm{dl}$ & $\mathrm{LDL}<100 \mathrm{mg} / \mathrm{dl}$ & $\mathrm{LDL}<100 \mathrm{mg} / \mathrm{dl}$ \\
\hline $\begin{array}{l}\text { Rozpoznana choroba naczyń, } \\
\text { przewlekła choroba nerek } \\
\text { w stadium 4. i } 5 \text {. }\end{array}$ & $\mathrm{LDL}<70 \mathrm{mg} / \mathrm{dl}$ & $\mathrm{LDL}<70 \mathrm{mg} / \mathrm{dl}$ & $\mathrm{LDL}<70 \mathrm{mg} / \mathrm{dl}$ & $\mathrm{LDL}<70 \mathrm{mg} / \mathrm{dl}$ \\
\hline
\end{tabular}

pacjentów zgłasza objawy mięśniowe w przebiegu stosowania statyn, którym towarzyszy prawidłowa lub nieznacznie podwyższona aktywność kinazy kreatynowej. Eksperci zalecają, aby pochopnie nie odstawiać statyny, skutkuje to bowiem brakiem redukcji ryzyka CV u nieleczonego pacjenta. Należy przeprowadzić wnikliwy proces diagnostyczny i wybrać optymalną dawkę silnie działającej statyny i najkorzystniejszy dla pacjenta sposób dawkowania (np. co 2-3 dni), dążąc do osiągnięcia celu terapii (odpowiednie do ryzyka CV obniżenie cholesterolu LDL) przy jednoczesnej dobrej tolerancji leku [10]. Do statyn o sile działania pozwalającej osiągnąć docelowe stężenie cholesterolu LDL obecnie eksperci zaliczają: atorwastatynę i rosuwastatynę. Ponieważ synteza cholesterolu organizmie ludzkim odbywa się we wczesnych godzinach rannych, a okres półtrwania $\left(T_{1 / 2}\right)$ powszechnie stosowanej w ubiegłych dekadach simwastatyny wynosi około 5 godzin $\left(\mathrm{T}_{1 / 2} \sim 5 \mathrm{~h}\right.$ ), podawanie tej statyny zalecano w godzinach wieczornych. Zarówno atorwastatyna, jak i rosuwastatyna mogą być podawane w ciągu całej doby ze względu na długie okresy półtrwania, które wynoszą odpowiednio 14 godzin (aktywne metabolity atorwastatyny 20-30 godz.) i 19 godzin [11]. Aby poprawić skuteczność terapii i zmniejszyć ryzyko CV pacjenta, a jednocześnie ograniczyć efekt utrudnionej współpracy lekarza i pacjenta, należy rozważyć leki złożone (połączenie leków hipotensyjnych i statyny) w terapii czynników ryzyka miażdżycy, w których samowolna modyfikacja dawek składowych preparatu nie jest możliwa.

Celem leczenia hipolipemizującego z zastosowaniem statyn jest osiąganie docelowego, dla danej populacji, stężenia cholesterolu frakcji LDL. Wyniki badania IMPROVE-IT udowodniły prawdziwość twierdzenia, że w przypadku terapii hipolipemizującej „im niższe stężenie cholesterolu, tym lepiej" [12]. U pacjentów bez rozpoznanej choroby tętnic docelowe stężenie cholesterolu LDL różni się w zależności od poziomu ryzyka pacjenta, obliczanego na podstawie tabeli SCORE, rekomendowanej przez Europejskie Towarzy- stwo Kardiologiczne (ESC, European Society of Cardiology) i Polskie Towarzystwo Kardiologiczne. Dla polskiej populacji należy stosować tablicę POL-SCORE na podstawie badań NATPOL (www.ptkardio.pl/Uaktualniona wersja oceny ryzyka sercowo naczyniowego PolSCORE_2015-2459) [13]. Aktualną wiedzę odnośnie do optymalnego docelowego stężenia cholesterolu LDL u pacjentów z nadciśnieniem tętniczym podsumowali eksperci Polskiego Towarzystwa Nadciśnienia Tętniczego w rozdziale stanowiącym fragment zasad postępowania w nadciśnieniu tętniczym. W nadciśnieniu tętniczym 1. i 2. stopnia, przy małym ryzyku CV, gdy występują 1-2 dodatkowe czynniki ryzyka, oraz w przypadku 1. stopnia nadciśnienia i występowaniu co najmniej 3 czynników ryzyka należy obniżyć stężenie cholesterolu LDL poniżej $115 \mathrm{mg} /$ dl. W sytuacji nadciśnienia 2. stopnia przy dodatkowych 3 lub więcej czynnikach ryzyka oraz u chorych z nadciśnieniem 3. stopnia, bez względu na liczbę dodatkowych czynników ryzyka, a także u wszystkich pacjentów wysokiego ryzyka (cukrzyca, cechy zmian narządowych, stadium 3 przewlekłej choroby nerek u pacjentów z nadciśnieniem tętniczym) należy obniżyć stężenie cholesterolu LDL do 100 mg/dl (tab. 1).

Podobnie jak w terapii hipolipemizującej, w leczeniu hipotensyjnym problemem wpływającym na nieskuteczność terapii bywa nieprzestrzeganie zaleceń lekarskich przez pacjentów. Wśród chorych leczonych z powodu nadciśnienia tętniczego w badaniu NATPOL 2011 skuteczną kontrolę wartości ciśnienia stwierdzono u 42\% osób. Konieczność bezterminowej terapii hipotensyjnej polegającej na codziennym przyjmowaniu kilku preparatów wiąże się z brakiem systematyczności leczenia lub odstawianiem leków po normalizacji wartości ciśnienia tętniczego krwi [3]. Większość pacjentów leczonych z powodu nadciśnienia tętniczego wymaga zastosowania 2 lub więcej leków, aby osiągnąc prawidłową kontrolę ciśnienia tętniczego krwi - poniżej 140/90 mm Hg. U osób z cukrzycą, docelowe wartości ciśnienia tętniczego krwi wynoszą: mniej niż 
140/85 mm Hg, a u pacjentów po 80. roku życia zalecane jest obniżanie ciśnienia skurczowego poniżej $150 \mathrm{~mm} \mathrm{Hg}$ (na podstawie badania HYVET [The HYpertension in the Very Elderly Trial]). U osób ze skurczowym nadciśnieniem tętniczym należy dążyć do obniżenia skurczowego ciśnienia tętniczego poniżej $140 \mathrm{~mm} \mathrm{Hg.} \mathrm{U} \mathrm{chorych} \mathrm{w} \mathrm{podeszłym} \mathrm{wie-}$ ku z 1. stopniem nadciśnienia tętniczego należy unikać zbyt dużego obniżenia ciśnienia rozkurczowego, czyli poniżej 65 mm Hg [14]. U większości pacjentów z nadciśnieniem tętniczym 2. i 3. stopnia należy rozpocząć leczenie od 2 preparatów, pamiętając, aby w razie potrzeby zwiększać dawki stosowanych leków, a nawet zastosować w programie leczenia 3 lub więcej specyfików (ok. 30\% pacjentów wymaga stosowania w terapii 3 leków). Aktualnie zaleca się stosowanie następujących kombinacji dwóch leków: inhibitor konwertazy angiotensyny (ACEI, angiotensin converting enzyme inhibitor) lub inhibitor receptora angiotensyny II (ARB, angiotensin receptor blocker) i antagonista wapnia, ACEl/ARB i diuretyk tiazydopodobny (diuretyki tiazydowe sa akceptowanym rodzajem leczenia, niemniej mniej skutecznie redukują ryzyko CV), ACEl i beta-adrenolityk, antagonista wapnia i beta-adrenolityk, antagonista wapnia i diuretyk tiazydowy/tiazydopodobny [14]. Eksperci podkreślają, że zastosowanie preparatów złożonych, dzięki redukcji częstości występowania działań niepożądanych, poprawie tolerancji przez chorego i polepszeniu komfortu życia, sprzyja przestrzeganiu zaleceń lekarskich [14, 15]. Plan leczenia powinien być indywidualnie dostosowywany do trybu życia pacjenta, jego potrzeb i możliwości finansowych, z maksymalnym uproszczeniem zaleceń i redukcją liczby przyjmowanych tabletek, zaangażowaniem członków rodziny chorego w proces leczenia [14]. Inercja terapeutyczna, a więc brak optymalizacji dawek leków przez lekarzy, była najczęstszym powodem nieprawidłowej kontroli ciśnienia tętniczego krwi w randomizowanych badaniach, takich jak: LIFE (Losartan Intervention For Endpoint Study; $\mathrm{n}$ = 9193), VALUE (The Valsartan Antihypertensive Long-term Use Evaluation) ( $n=15245$ ), ASCOT (Anglo-Scandinavian Cardiac Outcome Trial; $n=19$ 257) i ACCOMPLISH (Avoiding Cardiovascular Events in Combination Therapy in Patients Living with Systolic Hypertension; $n=11$ 506) [16].

Hipercholesterolemia i nadciśnienie tętnicze są schorzeniami często występującymi w skojarzeniu. Wyniki wielu randomizowanych badań, w których uczestniczyli pacjenci z nadciśnieniem tętniczym i hipercholesterolemią, wskazują, że jednoczesne skuteczne leczenie obu schorzeń optymalnie redukuje ryzyko CV. Dodanie atorwastatyny do leków hipotensyjnych: perindoprilu i amlodipiny w badaniu ASCOT wiązało się z istotnie większą redukcją ryzyka CV niż po zastosowaniu jej łącznie $z$ atenololem i diuretykiem [14]. W badaniu ASCOT leczeniem objęto 19342 pacjentów z nadciśnieniem tętniczym (w wieku 40-79 lat) i co najmniej 3 innymi czynnikami ryzyka CV. Pacjenci otrzymywali w leczeniu hipotensyjnym: amlodipinę z perindoprilem lub atenolol z diuretykiem tiazydowym (bendroflumetiazyd). Ponadto 10305 badanych pacjentów uczestniczących w ramieniu lipidowym badania: ASCOT-LLA, w terapii hipolipemizującej, otrzymywało atorwastatynę $10 \mathrm{mg}$ lub placebo (kryterium włączenia stanowiło stężenie cholesterolu $<250 \mathrm{mg} / \mathrm{dl}$ [6,5 mmol/l]). Okres leczenia hipolipemizującego zaplanowano na średnio 5 lat, badanie jednak przedwcześnie przerwano po 3,3 roku, stwierdzono bowiem zmniejszenie o 36\% częstości występowania pierwotnego puntu końcowego, jakim był zawał serca zakończony lub niezakończony zgonem, u pacjentów dodatkowo leczonych atorwastatyną (100 u leczonych atorwastatyną i 154 w grupie przyjmującej placebo, hazard względny [HR, hazard ratio] 0,64 [95\% Cl 0,50-0,83]; $p=0,0005)$. Korzyści z dołączenia atorwastatyny do leczenia hipotensyjnego zaobserwowano już w pierwszym roku leczenia. Stwierdzono też mniejszą o 27\% częstość występowania udarów mózgu, o 21\% wszystkich epizodów CV i o 29\% epizodów wieńcowych oraz zgonów podczas leczenia atorwastatyną w porówaniu z placebo, przy większej redukcji stężenia cholesterolu LDL. Obniżenie ryzyka CV podczas leczenia atorwastatyną wystąpiło niezależnie od wyjściowego stężenia cholesterolu całkowitego [17]. Badanie z zastosowaniem leczenia hipotensyjnego kontynuowano przez średnio 2,2 roku (do 2005 r.), proponując stosowanie atorwastatyny (ASCOT-LLA Extension) u wszystkich osób z podwyższonym stężeniem cholesterolu. Po zakończeniu badania średnie stężenie cholesterolu LDL w obu grupach leczenia hipotensyjnego średnie stężenie cholesterolu nie różniło się istotnie. Po dokładnej analizie historii pacjentów wykazano, że sposób leczenia hipotensyjnego miał duże znaczenie, stosując bowiem łącznie perindopril, amlodipinę i atorwastatynę zredukowano ryzyko CV o 53\%. Ryzyko sercowo-naczyniowe u badanych stosujących taką samą dawkę atorwastatyny oraz atenolol i diuretyki tiazydowy zmniejszyło się jedynie o 16\% [18]. Wyniki te dobitnie wskazują, że rodzaj terapii hipotensyjnej ma duże znaczenie.

Zarówno nadciśnienie tętnicze, jak i hipercholesterolemia, prowadząc do uszkodzenia funkcji śródbłonka oraz zwiększonej oporności na insulinę, sumują swój niekorzystny wpływ w procesie rozwoju miażdżycy tętnic. Statyny wywierają korzystny wpływ na funkcję śródbłonka, a także wywołują wiele pozytywnych efektów poza działaniem lipidowym, w tym redukują objętość i stabilizują blaszkę miażdżycową (zahamowanie aktywności metyloproteinaz), zmniejszają aktywność przewlekłego stanu zapalnego, obniżają stężenia białka C-reaktywnego (CRP, C-reactive protein), hamują trombogenezę w miejscu pęknięcia blaszki miażdżycowej, zmniejszają stres oksydacyjny i wazokonstrykcję, a także zmniejszają insulinooporność $[18,19]$. Wśród rekomendowanych leków hipotensyjnych poszczególne grupy leków, mimo skuteczności w obniżaniu ciśnienia tętniczego krwi, odznaczają się zróżnicowanym wpływem metabolicznym. Korzystne efekty metaboliczne wywieraja 
diuretyki tiazydopodobne, beta-adrenolityki o działaniu wazodylatacyjnym oraz leki hamujące na układ renina-angiotensyna-aldosteron (RAA). Antagoniści wapnia to leki neutralne metabolicznie, dlatego podkreśla się ich przydatność w leczeniu skojarzonym z lekami blokującymi układ RAA u chorych ze współistniejącymi zaburzeniami gospodarki lipidowej i/lub węglowodanowej. U pacjentów z nadciśnieniem tętniczym współistniejącym z uszkodzeniami narządowymi, wysokim i bardzo wysokim ryzykiem sercowo-naczyniowym zespołem metabolicznym i/lub cukrzycą preferowanymi lekami są ACEI. W metaanalizach badań randomizowanych, w których obejmowano leczeniem chorych z nadciśnieniem tętniczym, stwierdzono przewagę ACEI nad ARB. Spośród 20 badań randomizowanych, w których obserwowano odpowiedź 158998 pacjentów z nadciśnieniem tętniczym na programy leczenia z zastosowaniem leków wpływających na układ RAA, stwierdzono 5-procentową redukcję śmiertelności całkowitej i 7-procentową - sercowo-naczyniowej. Efekt ten jednak był związany z redukcją śmiertelności w 3 badaniach z zastosowaniem perindoprilu, takich jak: ASCOT-BPLA, ADVANCE (Action in Diabetes and Vascular Disease-Preterax and Diamicron MR Controlled Evaluation), HYVET. Nie wykazano istotnego zmniejszenia śmiertelności u pacjentów leczonych za pomocą ARB. Różnica w efekcie leczenia obiema grupami leków była istotna statystycznie [20]. Wpływ perindoprilu na redukcję ryzyka CV może wynikać z wysokiego powi- nowactwa tkankowego i większej zdolności selektywnego wiązania bradykininy i hamowania jej rozkładu w porównaniu z innymi lekami. W ten sposób bradykinina, działając przeciwzapalnie, wazodylatacyjnie i kardioprotekcyjnie, synergistycznie wspomaga wpływ hipotensyjny i plejotropowy perindoprilu, ograniczając proces rozwoju powikłań nadciśnienia tętniczego [21].

Działania dążące do wydłużenia życie Polaków o kolejne lata składają się na skuteczne ograniczanie - zarówno za pomoca metod niefarmakologicznych, jak i poprawy skuteczności farmakoterapii - podstawowych czynników ryzyka miażdżycy, takich jak hipercholesterolemia, nadwaga i otyłość, nadciśnienie tętnicze, palenie tytoniu. Kompleksową terapię należy rozważać już u młodszych pacjentów, dążąc do osiągania wartości zalecanych jako cel terapii we wszystkich grupach ryzyka sercowo-naczyniowego. Preparaty złożone w terapii nadciśnienia tętniczego i hipercholesterolemii są dobrym sposobem na poprawę kontroli wartości ciśnienia tętniczego i przestrzeganie zaleceń lekarskich. Zastosowanie w terapii skojarzonej perindoprilu i atorwastatyny, o addytywnym wpływie na ryzyko sercowo-naczyniowe, oraz uzupełnienie leczenia w celu wzmocnienia efektu hipotensyjnego o antagonistę wapnia stanowią bezpieczną, skuteczną i wygodną opcję w terapii czynników ryzyka miażdżycy. Przyszłością dla polskich pacjentów jest stosowanie tej terapii w postaci preparatu złożonego, dostępnego już w krajach Unii Europejskiej.

\section{Abstract}

Hypertension and hypercholesterolemia are the most common risk factors for cardiovascular events, in the Polish population. Hypercholesterolemia is up on about $2 / 3$, while hypertension is affecting about $1 / 3$, of the adult Poles. Both risk factors are poorly controlled in Polish patients. In order to improve the effectiveness of therapy and reduce cardiovascular risk, combination drug theraphy without possibility of modyfication of component doses, should be considered. The goal of cholesterol lowering treatment, with the use of first choice drug: statins, is LDL cholesterol level. The majority of hipertensive patients requires two or more drugs to achieve the proper control of blood pressure, $<140 / 90 \mathrm{~mm} \mathrm{Hg}$. Application of more than one compounds in one preparation reduce the incidence of adverse effects and improves treatment adherence. The drug choice is important, because, for example, in an ASCOT study, combining the atorvastatin with perindopril and amlodypine, reduced the CV risk of $53 \%$, but with atenolol and thiazid only of about $16 \%$. Both hypertension and hypercholesterolemia impairs edothelial function, increase insulin resistance, summarize their negative impac. Theraphy with antihypertensives and statin combination is a good way to improve blood pressure and cholesterol control.

Key words: ACEI, amlodypine, statin

Folia Cardiologica 2016; 11, 5: 427-432 


\section{Piśmiennictwo}

1. World Health Organisation Regional Office for Europe: mortality indicator database: mortality indicators by 67 causes of death, age and sex (HFA-MDB). Updated: October 2015. data.euro.who.int/hfamdb/ Data dostępu: 5.01.2016 r.

2. Bandosz P., O'Flaherty M., Drygas W. i wsp. Decline in mortality from coronary heart disease in Poland after socioeconomic transformation: modelling study. BMJ 2012; 344-354.

3. Zdrojewski T., Rutkowski M., Bandosz P. i wsp. Prevalence and control of cardiovascular risk factors in Poland. Assumptions and objectives of the NATPOL 2011 Survey. Kardiol. Pol. 2013; 71: 381-392.

4. Szostak-Węgierek D., Waśkiewicz A. Metabolic disorders in women at procreative age living in Warsaw. Rocz. Panstw. Zakl. Hig. 2015; 66: $245-251$.

5. Jankowski P., Czarnecka D., Wolfshaut-Wolak R. i wsp. Secondary prevention of coronary artery disease in contemporary clinical practice. Cardiol. J. 2015; 22: 219-226.

6. Jardim T.V., Sousa A.L., Povoa T.I. i wsp. The natural history of cardiovascular risk factors in health professionals: 20-year follow-up. BMC Public Health 2015; 15: 1111-1118.

7. Bandosz P., O'Flaherty M., Rutkowski M. i wsp. A victory for statins or a defeat for diet policies? Cholesterol falls in Poland in the past decade: a modeling study. Int. J. Cardiol. 2015; 185: 313-319.

8. Baigent C., Blackwell L., Emberson J. i wsp. Efficacy and safety of more intensive lowering of LDL cholesterol: a meta-analysis of data from 170,000 participants in 26 randomised trials. Lancet 2010; 376: 1670-1681.

9. De Vera M.A., Bhole V., Burns L.C., Lacaille D. Impact of statin adherence on cardiovascular disease and mortality outcomes: a systematic review. Br. J. Clin. Pharmacol. 2014; 78: 684-698.

10. Starzyk K., Wożakowska-Kapłon B. Objawy mięśniowe w przebiegu stosowania statyn - fakty, mity, rzeczywistość i stanowiska ekspertów Folia Cardiol. 2015; 10: 354-360.

11. Plakogiannis R., Cohen H. Optimal low-density lipoprotein cholesterol lowering - morning versus evening statin administration. Ann. Pharmacother. 2007; 41: 106-110.
12. Cannon C.P., Blazing M.A., Giugliano R.P. i wsp. IMPROVE - IT Investigators Ezetimibe Added to Statin Therapy after Acute Coronary Syndromes. N. Engl. J. Med. 2015; 372: 2387-2397.

13. Tykarski A., Narkiewicz K., Gaciong Z. i wsp. Zasady postępowania w nadciśnieniu tętniczym - 2015 rok. Arterial Hypertens. 2015; 19: 53-83.

14. Zdrojewski T., Jankowski P., Bandosz P. i wsp. Nowa wersja systemu oceny ryzyka sercowo-naczyniowego i tablic SCORE dla populacji Polski. Kardiol. Pol. 2015; 73: 958-961.

15. Wożakowska-Kapłon B., Filipiak K.J., Czarnecka D. i wsp. Miejsce leków złożonych w terapii nadciśnienia tętniczego - aktualne problemy w Polsce. Stanowisko Ekspertów Polskiego Towarzystwa Nadciśnienia Tętniczego i Sekcji Farmakoterapii Sercowo-Naczyniowej Polskiego Towarzystwa Kardiologicznego. Kardiol. Pol. 2013; 71: 433-438.

16. Kjeldsen S.E., Julius S., Dahlöf B., Weber M.A. Physician (investigator) inertia in apparent treatment-resistant hypertension - insights from large randomized clinical trials. Lennart Hansson Memorial Lecture. Blood Press. 2015; 24: 1-6.

17. Sever P.S., Dahlöf B., Poulter N.R. i wsp. Prevention of coronary and stroke events with atorvastatin in hypertensive patients who have average or lower-than-average cholesterol concentrations, in the Anglo-Scandinavian Cardiac Outcomes Trial - Lipid Lowering Arm (ASCOT-LLA): a multicentre randomised controlled trial. Lancet 2003; 361: 1149-1158.

18. Sever P., Dahlöf B., Poulter N. i wsp. Potential synergy between lipid-lowering and blood pressure-lowering in the Anglo-Scandinavian Cardiac Outcomes Trial. Eur. Heart J. 2006; 27: 2982-2982.

19. Starzyk K., Wożakowska-Kapłon B. Statyny w terapii chorego z nadciśnieniem tętniczym - czy tylko działanie hipolipemizujące? Arterial Hypertens. 2010; 14: 157-165.

20. van Vark L.C., Bertrand M., Akkerhuis K.M. i wsp. Angiotensin-converting enzyme inhibitors reduce mortality in hypertension: a meta-analysis of randomized clinical trials of renin-angiotensin-aldosterone system inhibitors involving 158,998 patients. Eur. Heart J. 2012; 33: 2088-2097.

21. Kluk M.K., Wożakowska-Kapłon B. Perindopril - nieznane oblicza znanego leku. Folia Cardiol. 2014; 9: 173-178. 